\title{
Karayolu Yük Taşımacılığının Ekonomik Büyüme ve Ticaret Hacmi Üzerindeki Etkisine Yönelik Ampirik Bir Analiz \\ (Araştırma Makalesi)
}

An Empirical Analysis of the Effect of Road Freight Transport on Economic Growth and Trade Volume

Doi: 10.29023/alanyaakademik.700146

\section{Deniz MACIT}

Dr. Öğr. Üyesi, Alanya Alaaddin Keykubat Üniversitesi, Gazipaşa Havacılık ve Uzay

Bilimleri Fakültesi,

deniz.macit@alanya.edu.tr

Orcid No: 0000-0002-7439-7202

Bu makaleye atıfta bulunmak için: Macit, D. (2020). Karayolu Yük Taşımacıllı̆ııın Ekonomik Büyüme ve Ticaret Hacmi Üzerindeki Etkisine Yönelik Ampirik Bir Analiz. Alanya Akademik Bakış, 4(3), Sayfa No. 843-860.

\section{ÖZET}

\section{Anahtar kelimeler:}

Yük Taşımacılı̆̆l,

Karayolu Yük

Taşımacıllı̆ $l$

Makale Geliş Tarihi: 06.03.2020

Kabul Tarihi:

17.09.2020

Keywords:

Freight

Transportation, Road

Freight

Transportation
Taşımacılık faaliyetlerinin türev talep olması nedeni ile ekonomik büyüme ile birlikte değerlendirildiğinden bu iki unsur arasındaki ilişkinin analiz edilmesi son derece önemlidir. Ayrıca taşımacılık altyapısına yapılan yatırımların yüksek maliyetleri ve uzun vadeli karakteri göz önüne alındığında, politika yapıcıların altyapı projelerine karar vermek için yük taşımacıllı̆ı ile ilgili ampirik sonuçlara ihtiyaçları bulunmaktadır. Çalışmanın temel amacı, karayolu ulaştırma modu çerçevesinde gerçekleştirilen yük taşımacıllğ büyüme ve ticaret hacmi üzerinde bir etkisinin olup olmadiğının belirlenmesidir. Ticaret ve GSYİH ile Türkiye'de yük taşımacıllı̆̆ arasındaki ilişsiyi ortaya koymak için 1988-2018 arası döneme ilişkin yıllık veriler ile regresyon analizi gerçekleştirilmiştir. Çalışmanın temel bulgusuna göre yük taşımacıllı̆̆ ile GSYIH ve toplam ticaret hacmi üzerinde anlamlı bir ilişsi tespit edilmiştir. Bu ilişkiye göre karayolu yük taşımacılı̆̆ $\% 1$ arttı̆̆ında GSYIH'nın yaklaşık olarak 0.65 , ticaretin ise 0.70 arttı̆̆ tahmin edilmiştir. Ekonometrik analiz ile karayolu yük taşımacıllğında meydana gelen değişimin ekonomik büyüme ve ticaret hacmini ne yönde değiş̧tirdiği ortaya konduktan sonra karayolu yük taşımacılığının geliştirilmesine yönelik öneriler sunulmuştur.

\section{ABSTRACT}

Since the transport activities are evaluated together with the economic growth due to the derivative demand, it is extremely important to analyze the relationship between these two factors. Investments in transportation infrastructure have high costs and long-term character. Policy makers need empirical results on freight transport to decide on infrastructure projects. The main purpose of the study is to determine whether the increase or decrease in the amount of freight transport carried out within the framework 
of road transport mode has an impact on economic growth and trade volume. To reveal the relationship between trade and GDP and freight transport, annual data for the period 1988-2018 and regression analysis were performed. According to the main findings of the study, a significant relationship was found between freight transport and GDP and total trade volume. According to this relationship, it is estimated that when road freight transportation increased by 1\%, GDP increased by approximately 0.65 and trade by 0.70. After showing how the change in road freight transport changed the economic growth and trade volume by econometric analysis, suggestions for the development of road freight transportation were presented.

\section{GİRIŞ}

Küreselleşmenin yanı sıra teknolojideki hızlı gelişimler ile birlikte ticaret hacminin de genişlemesi ile ulaştırma faaliyetleri günümüzde önemli bir boyuta ulaşmıştır. Küresel düzende artan rekabetin ülkeleri dış piyasalara yönlendirmesiyle ulaştırma faaliyetlerinin gelişimi ivme kazanmış ve bu faaliyetlere duyulan ihtiyaç artmıştır. Dünya ticaretinde ve ülke ekonomilerinde önemli bir yeri bulunan ulaştırma ekonomisinin bu önemi her geçen gün artmaktadır.

Ulaştırma bir sektör olarak kalkınmayı desteleyen, bölgelerarası dengesizliği gideren etkilere sahip bir yapıdadır. Bu destekleyici ve tamamlayıcı nitelikteki etkileri sayesinde ulaştırma politikaları ekonomik gelişme aracı olarak görülmektedir (Coyle vd., 2011: 34). Tüm ulaştırma modlarının ekonomiye olan katkıları tartışmasız bir gerçektir. Ulaştırma sektöründe yapılan faaliyetler ekonomik boyutları açısından üretim-tüketim arasında bir köprü görevi görmektedir. Dolayısıyla ülke ekonomilerinde ulaştırma faaliyetlerinin önemli bir yeri bulunmaktadır. Ulaştırma faaliyeti insanların ve malların bir yerden bir yere taşınmasını sağladığı için her daim gündemde olan bir konudur. Ulaştırmanın ekonomik ve toplumsal kalkınmadaki etkin rolü göz önünde bulundurulduğunda bu sektörle ilgili ortaya konacak teorik ve pratik araştırmaların bulgularının ülke yöneticileri açısından politika oluşturma süreçlerine katkı sağlayacağı bir gerçektir.

Ekonomik bir sektör olması açısından yük taşımacılığı da ticaret, sanayi, tarım sektörü gibi çeşitli sektörlerle karşılıklı etkileşim içerisinde bulunmaktadır. Ülkemizde karayolu yük taşımacılığının diğer ulaşım türlerine göre yüksek bir payı bulunmaktadır.

Ülkemizde ve dünyada ekonomik açıdan önemli bir yere sahip bulunan karayolu yük taşımacılığı sektörü sayesinde üretilen malların büyük çoğunluğu bu nakliye yöntemi ile pazarlara taşınabilmekte ve bu sektör ekonomik döngü içerisinde kendine önemli bir yer bulmaktadır (Karabıçak ve Gündoğdu, 2014: 181).

$\mathrm{Bu}$ çalışmada karayolu ulaştırma modunda yapılan yük taşımacılığının ekonomik açıdan değerlendirilmesi amaçlanmaktadır. Bu çerçevede Türkiye'de 1988-2018 arası dönemde yapılan yük taşımacılığı ile GSYİH ve toplam ticaret hacmi arasındaki ilişki ortaya konmaktadır. Çalışma kapsamında öncelikle çeşitli ulaştırma modlarına yönelik olarak yapılan ve yük taşımacılığının ekonomi ile ilişkilerini ele alan ulusal ve uluslararası alandaki bazı araştırmalara yer verilmekte daha sonra kavramsal çerçeveye kısaca değinildikten sonra analiz bulguları aktarılmakta ve değerlendirme kısmı ile çalışma sonlandırılmaktadır. 


\section{LITERATÜR}

Taşımacılık faaliyetleri ve ekonomik göstergeler arasındaki ilişkileri inceleyen ampirik çalışmalar uluslararası literatürde farklı şekillerde yer alsa da ulusal alanda yapılan çalışmalar incelendiğinde araştırmaların son derece kısıtlı olduğu görülmektedir. Taşımacılık konusunda yapılan araştırmalar genel olarak ayrıştırma üzerine odaklanmakta ya da farklı ulaştırma modalarını içermektedir. Bu kısımda öncelikle karayolu yük taşımacılığına ilişkin literatür araştırmasına yer verilmekte daha sonra ise diğer ulaştırma modları çerçevesinde yapılan seçilmiş bazı araştırma sonuçları açıklanmaktadır.

Bozkurt vd. (2017) tarafından yapılan çalışmada, 1995-2015 dönemine ilişkin olarak Türkiye ve Avrasya Ekonomilerinde taşımacılık sektörü ile ekonomik büyüme arasındaki ilişki panel veri analizi ile incelenmiştir. Çalışmanın temel sonucu, ekonomik büyüme ile taşımacılık sektörü arasında eşbütünleşme olduğu yönündedir.

Alises vd. (2014), 1999-2007 dönemi için İngiltere ve İspanya'daki karayolu tonu-km / GSYİH ilişkisinin evrimini analiz ederek son ayrışma eğilimlerini karşılaştırmaktadırlar. Hem ekonomik yapılar hem de karayolu ulaşım yoğunluğu düzeyleri arasındaki farklılıklar hakkında genel bir bakış sunmaktadırlar. Ayrıca her ülkede GSYİH birimi başına kamyon trafiğinin evrimini açıklayan değişkenleri belirlemek için bir ayrışma analizi gerçekleştirmişlerdir. Araştırma sonuçları, GSYİH içindeki hizmetlerin artan payının her iki durumda da karayolu taşımacılığı talebinin azalmasına önemli ölçüde katkıda bulunduğunu göstermektedir.

Rashidi ve Samimi (2012), kamyon taşımacılığı verimlilik artışı ile ekonomik göstergeler arasındaki ilişkiyi incelemektedir. Bu amaçla 2001-2007 dönemine ilişkin ekonomik faaliyet düzeyleri kullanılmaktadır. İstihdam ve GSYİH dahil ekonomik göstergeler ile ulaşım göstergesi olarak hareketlilik arasındaki tanımlayıcı istatistikler ve haritalar kullanılarak analiz gerçekleştirilmiştir. Taşımacılık verimliliği artış oranlarının yüksek olduğu ve düşük büyüme, hatta düşüşün olduğu büyükşehir istatistik alanlarını belirleyen faktörlerin genel ekonomik koşullardan ve aynı zamanda toplumların ekonomik kalkınma teşviklerinden ve yaratıcılığından etkilendiği temel bulgusu ortaya konmuştur. Kaynak ve Mert (2009) tarafından yapılan analiz sonucunda, GSYİH'daki oransal artışın, taşımacılık faaliyetlerinde kendisinden daha fazla bir artışa neden olduğu ortaya konmaktadır.

McKinnon (2007) çalışması; 1997-2004 yılları arasında, Avrupa ve ABD'deki ayrıştırma konusundaki önceki araştırmaları ve GSYİH/yük ton-km esnekliğindeki son eğilimleri gözden geçirmektedir. İngiltere'de gözlenen ayrışmanın 12 olası nedenini, çok çeşitli İngiliz ve Avrupa kaynaklarından yayınlanan istatistikleri kullanarak incelemektedir. İngiliz karayolu taşımacılık pazarının yabancı operatörler tarafindan artan nüfuzu, karayolu taşımacılığının navlun pazarındaki payında bir düşüş ve karayolu navlun oranları, ayrıştırmanın yaklaşık üçte ikisinin etkisi ölçülebilen üç faktörden kaynaklandığını göstermektedir. Bu alanda McKinnon (2004) tarafindan yapılan benzer bir çalışma ise İngiltere'de bir hafta boyunca kamyon taşımacılı̆̆ hizmetlerinin tamamen kesilmesinin olası sonuçlarını araştırmaktadır. Araştırma sonuçları; envanter seviyelerini, teslimat sürelerini, karayolu taşımacılığına bağımlılığı ve kritik sektörlerde ikame firsatlarını analiz ederek, hızlı bir ekonomik çöküş oranı öngörmektedir. Bu araştırma bulguları taşımacılık sektörünün ekonomi için büyük bir güç kaynağı olduğunu desteklemektedir. 
Zhu ve diğ. (2007), 1994-2004 arası döneme ilişkin; reel GSYİH büyüme oranı, yıllık kargo ulaştırma hacmi büyüme oranına ilişkin regresyon analizi gerçekleştirmişlerdir. Çin'de lojistik ve ekonomik kalkınma arasındaki ilişkinin etkileşimli olduğunu sonucuna ulaşılmıştır.

Kayode vd. (2013) tarafından yapılan araştırma 1977-2009 dönemi için Nijerya'da ulaştırmaya yapılan kamu sektörü yatırımının ekonomik büyüme üzerindeki etkisini araştırmaktadır. Çalışmanın ampirik modeli, ulaştırma yatırımlarının üretim fonksiyonuna girdi olarak girdiği içsel büyüme çerçevesinden, Sıradan En Küçük Kareler (OLS) tahmin tekniği ve değişkenler üzerinde yapılan zaman serisi özellikleri testleri kullanılarak geliştirilmiştir. Bulgular, ulaşımın Nijerya'daki ekonomik büyümenin belirlenmesinde önemsiz bir rol oynadığını ortaya koymaktadır.

Karayolu taşımacılığı dışında farklı ulaştırma modları için yapılan çalışmalardan biri de Hakim ve Merkert (2016) tarafından yapılan havayolu taşımacılığına yönelik analizdir. Güney Asya bağlamında hava taşımacılığı ve ekonomik büyüme arasındaki nedensel ilişki incelenmektedir. 1973-2014 yıllarına ilişkin panel veriler ile Pedroni/Johansen eşbütünleşme yöntemleri ve Granger uzun dönem, Wald kısa dönem nedensellik testleri uygulanmıştır. Bu çalışmanın temel bulgusu, GSYİH'dan hava kargo taşımacılığına tek yönlü bir nedensellik ilişkisinin olduğudur. Sezer (2018)'de lojistik sektörü ile ekonomik büyüme arasındaki nedensellik ilişkisini test etmiştir. BRICS ülkeleri (Brezilya, Rusya, Hindistan, Çin, Güney Afrika) ve Türkiye, yıllık GSYİH büyüme oranı ve metrik ton cinsinden havayolu yük taşımacılığı işlem hacmi verileri kullanılarak 1993-2017 döneminde gerçekleştirilen analizlere dahil edilmiştir. Çalışmanın elde edilen sonuçları, BRICS ülkeleri ve Türkiye için havayolu yük taşımacılığı ile GSMH artışı arasında nedensel bir ilişki olmadığını ortaya koymaktadir.

Demiryolu ve karayolu ulaştırmayı birlikte değerlendiren bir çalıma ise Pradhan ve Bagchi (2013) tarafından yapılmıştır. Bu iki ulaştırma modunun 1970-2010 döneminde Vektör Hata Düzeltme Modeli (VECM) ile Hindistan'daki ekonomik büyüme üzerindeki etkisi incelenmektedir. Çalışmanın temel bulgusu; karayolu taşımacılığı ve ekonomik büyüme arasında çift yönlü nedensellik bulunduğunu yönündedir.

$\mathrm{Bu}$ çalışmada ise ekonomik büyüme ile ticaret hacmi arasındaki ilişkiyi araştıran literatüre katkı sağlamak amacı ile Türkiye'deki karayolu yük taşımacılığı analiz edilmektedir.

\section{KAVRAMSAL ÇERÇEVE}

\subsection{Ulaşım ve Taşımacılık Kavramları}

Ulaştırma, ihtiyaçları giderme amacıyla insanların ve eşyaların zaman ve yer faydası oluşturacak biçimde yer değiştirmesini sağlayan bir hizmet olarak tanımlanmaktadır (Barda, 1970: 16). Ulaşım, yük ve yolcuların farklı ulaştırma araçları ile bir noktana başka bir noktaya taşınabilmesini sağlayan bir hizmet türüdür (Gündoğdu, 2013: 2). Taşımacılık, müşterilerin ihtiyaçlarını karşılamak amacı ile talep edilen ürün/ürünlerin ya da insanların ihtiyaç duyulan yere ulaştırılması faaliyeti olarak tanımlanmaktadır. Taşımacılık modu ise taşımanın ne şekilde yapılacağını belirtmektedir (Bowersox vd., 2013: 187).

Eşyanın araca yüklenerek taşıyıcıya iletildiği, yolcunun araca binerek istediği varış noktasına ulaştırılmasında kara yolu bağlantılarının kullanıldığı taşımacılık modu, karayolu taşımacılığı olarak adlandırılmaktadır (Kögmen, 2014: 3). Arz ve talep arasındaki bağlantıyı sağlayan ve 
aynı zamanda ekonomik açıdan büyük öneme sahip olan karayolu taşımacılığı modern ekonomik yapıların temel unsurlarından birini oluşturmaktadır.

Karayolu yük taşımacılığı kavramı ise, belirli bir ücret karşılığında malların bir yerden bir yere karayolu bağlantıları kullanılarak taşınmasını ifade etmektedir. Bu tanım çerçevesinde ele alındığında karayolu yük taşımacılığının; taşınacak bir malın varlığı, belirli bir ücret karşılığı malın taşınma işleminin gerçekleştirilmesi, karayolu bağlantısı ile taşımanın yapılması gibi temel unsurları bulunmaktadır.

\subsection{Karayolu Yük Taşımacılığı ve Ekonomi Arasındaki Bağlantılar}

Bir bütün olarak ulaştırma sektörü, üretilen mal ve hizmetlerin aktarımını sağlayıp, katma değer oluşturduğu ve ekonomik gelişmeye katkı sağladığ 1 için ekonominin de temel parçasını oluşturmaktadır. Ulaştırma sektörü ekonomiye katkı sağladığı kadar ekonomik gelişmelerden de beslenmektedir. Yük trafiğinin ekonomilerin büyüme dönemlerinde arttığı tam tersine negatif büyüme dönemlerinde ise bu trafiğin düştüğü görülmektedir (Çancı ve Güngören, 2013: 199). Ulaştırma faaliyetlerinin ekonomideki temel fonksiyonlarından bir tanesi; üretici ve tüketici arasındaki zaman-mekân boşluklarını ortadan kaldırmaya yardımcı olmaktır (Gwilliam, 1964: 30).

Taşımacılığın ekonomiye olan etkileri iki şekilde gerçekleşmektedir. Bunlardan ilki olan doğrudan etki; yük taşımacılığgndan elde edilen ücret olan navlundan elde edilen gelirler ve bu sektörde faaliyet gösterenlerin elde ettikleri ücret gelirlerinden kaynaklanmaktadır. Dolaylı yoldan ise; taşımacılığın ekonomik faaliyetler için bir çekim gücü oluşturulmasından kaynaklanmaktadır (Çancı ve Güngören, 2013: 209). Aşağıdaki şekilde ulaştırma-ekonomi arasındaki temele bağlantılar (Caid, 2004: 13) yer almaktadır.

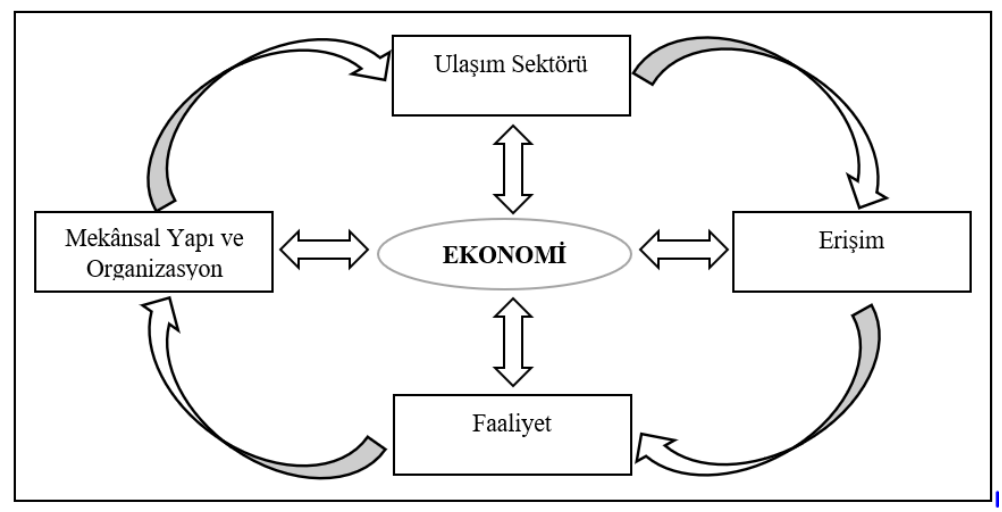

Şekil 1. Ulaştırma ve Ekonomik Büyüme Arasındaki Bağlantı

Bağlantının temelinde dört ana unsurdan etkilenen ekonomi bulunmaktadır. Ulaştırma sistemindeki politika değişiklikleri bölgelerin yerel erişilebilirliğini etkilemektedir. Ulaşımın ekonomiye olan etkileri genellikle; kamu harcamaları, milli gelir gibi ulusal hesaplar aracılığı ile ulusal düzeyde ölçülür (Caid, 2004: 13).

Ulaştırma sektörü ekonominin önemli bir unsurudur ve ekonomik büyüme ile katma değer yaratmaya önemli katkılar sağlamaktadır. 


\subsection{Karayolu Yük Taşımacılığında Yaşanan Sorunlar}

Karayolu yük taşımacılığı sektörü petrol fiyatlarının yüksek olmasından kaynaklı yüksek maliyetlerle çalışma nedeni ile kendi içinde zorluklarla karşı karşıyadır. Küresel ve bölgesel gelişmeler ulusal sektörün istikrarlı büyümesini engellemektedir. Ticaret politikalarındaki korumacılık, Brexit süreci, AB'nin büyüme problemleri Türkiye'nin taşımacılık sektörünün gelişimini önemli ölçüde kısıtlamaktadır (KPMG, 2020: 10). Yük taşımacıllğının ton-km maliyeti, kullanılan enerji miktarı ve tüketilen enerji türü, kaza riskinin yüksek olması (2018 yılında toplam kaza saylsı yaklaşık 1 milyon 230 bin olarak gerçekleşmiştir (TÜiK)) gibi dezavantajları bulunmaktadır (Keçeci: 2006). Sektörün en büyük gider kaleminin yakıt olmasından dolayı yakıt fiyatlarında yaşanan dalgalanmalar sektörü olumsuz etkilemektedir. Şirketlerin uzun vadeli sözleşmeler yapması ile fiyatları değiştirme şansı bulunmayan nakliyecilerin üzerinde fiyat dalgalanmaları bir yük oluşturmaktadır.

Karayolu sistemindeki denetim eksiklikleri ve altyapı eksiklikleri gibi nedenler sektörde faaliyet gösteren firmaların maliyetlerini arttırmaktadır. Karayolu taşımacılığında maliyetlerin yüksek oluşu ise belirli bölgelerde yoğunlaşma yaratmakta ve üretim-tüketim dengesini bozucu yönde etki yapmaktadır. Ülkemiz petrol ithal eden bir konumda olduğu için karayolu ulaştırma maliyetlerinin yüksek olması, netice olarak mal ve hizmetlerin fiyatlarını arttırıcı yönde baskı yaratmaktadır. Yüksek maliyetli bir ulaştırma politikasının sürdürülmesi hanehalkının gelirini düşürücü etkiler yaratmaktadır (Kaya, 2008: 34).

Karayolu sistemindeki denetim eksiklikleri ve altyapı eksiklikleri gibi nedenler sektörde faaliyet gösteren firmaların maliyetlerini arttırmaktadır. Karayolu taşımacıllı̆̆ında maliyetlerin yüksek oluşu ise belirli bölgelerde yoğunlaşma yaratmakta ve üretim-tüketim dengesini bozucu yönde etki yapmaktadır. Ülkemiz petrol ithal eden bir konumda olduğu için karayolu ulaştırma maliyetlerinin yüksek olması, netice olarak mal ve hizmetlerin fiyatlarını arttırıcı yönde baskı yaratmaktadır. Yüksek maliyetli bir ulaştırma politikasının sürdürülmesi hanehalkının gelirini düşürücü etkiler yaratmaktadır (Kaya, 2008: 34).

Sektörün yaşadığı sorunlar uluslararası açıdan incelendiğinde ise aşağıdaki temel konularla karşılaşıldığı görülmektedir (Dünya, 2017; KPMG, 2020: 10; Keçeci: 2006):

- Karayolu taşımacılığında uluslararası alanda sektörün en büyük sorunu iç gümrüklere uğrama zorunluluğu ve dış gümrüklerdeki bekleme sürelerinin uzunluğudur.

- Karayolu ile yapılan taşımacılık uluslararası politik ve iktisadi konjonktürde meydana gelen gelişmelere karşı hassas ve kırılgan bir yapı sergilemektedir. Bu hassas ve kırılgan yapısı sayesinde birtakım dezavantajları bulunmaktadır.

- Birçok ülke uluslararası taşımacılıktan aldıkları payı arttırmak ve ulusal taşımacılık sektörlerini korumak gibi temel amaçlar ile yabancı taşıııııların geçişlerini kısıtlamaktadır. Yurt dışına faaliyette bulunan taşıyıcılarımız bu zorluklarla mücadele etmek zorunda kalmaktadir.

- Nitelikli insan kaynağı, fiziki altyapı ve yatırımların yetersiz olması nedeni ile yeterli miktarda yatırımcı çekilememektedir.

\section{TÜRKİYE'DE KARAYOLU YÜK TAŞIMACILIĞI}

Karayolu ile yapılan taşımacııık faaliyetleri, insanlık tarihi kadar eskilere dayanmaktadır ve avcı topluluklarda avlardan oluşan yüklerin evcilleştirilen hayvanlar ile taşınmasıyla başlamıştır (Doğan, 2014: 9).

848 
Türkiye'nin karayolu taşımacılığının tarihsel gelişimi incelendiğinde sürekli artan bir ivme ile gelişme yaşadığı görülmektedir. Ülkemiz mevcut coğrafi konumu dikkate alındığında, transit taşımacılığa elverişli ve doğu ile batı arasında bir köprü görevi gören konumu sayesinde taşımacılık faaliyetlerinde geçmişten bugüne ön planda olmuştur.

1923-1950 arası dönemde motorlu araç sayısının kısıtlı olmasından dolayı hükümet demiryolu yatırımlarına yoğunlaşmıştır (Kögmen, 2014: 3). Küreselleşmenin de etkisiyle birlikte dünya genelinde artan ticaret hacmi ülkemizde de etkilerini göstermiştir. 1950'li yıllarda modern karayolu taşımacılığı adına ülkemizde önemli gelişmeler yaşanmıştır. 1950'li yıllardan karayolları yapımları hız kazanmıştır (Karluk, 2009: 261). Ülkemizde 1950'li yıllar ile birlikte Marshall Yardımlarının etkileri ile birlikte üstünlük, demiryolundan karayolu ulaşımına geçmiştir (Deniz, 2016: 135). Ayrıca 1950'de karayolunun geliştirilmesi için Karayolları Genel Müdürlüğü kurulmuştur. 1970'li yıllar yol uzunluklarını arttırmaktan ziyade, fiziksel kapasitenin arttırıldığı yıllar olmuştur (KGM, 2005: 17). 1980'ler ile birlikte uygulamaya konan teşvik önlemleri neticesinde artan motorlu araç rakamları karayolu taşımacılığında hızlı bir gelişim yaşanmasını sağlamıştır. Ayrıca bu dönemde ihracata dayalı büyüme modelinin benimsenmesiyle artan dış ticaret hacmi taşımacılık rakamlarının da hızla artmasına yol açmıştır.

1990’lı yıllar ise hükümetin ulaştırma sektörü için yeni politikaların belirlendiği bir dönem olmuştur. Bu çerçevede; eğitimli teknik personelin yetiştirilmesi, kaynakların etkin kullanımı, taşımacılığın denetimi ve Avrupa üzerinden yapılacak taşımacılık faaliyetleri için yeni seçeneklerin oluşturulması gibi planlamalar yapılmıştır (TCUB, 1993). 2000'li yıllara gelindiğinde ise karayolu taşımacılık sektörü dünya genelinde temel ulaşım modu haline gelmiştir.

Karayolu taşıma modunun başlangıç ile bitiş noktaları arasında aktarma yapmadan taşımaya imkân sağlayabilmesi ve kısa mesafeli taşımalarda nispeten daha ekonomik olması gibi birtakım avantajlarının bulunmasının yanı sıra, birim taşıma maliyetleri, kullanılan enerji türü ve miktarı, konjonktürel değişikliklerden kolay etkilenmesi gibi bazı dezavantajları da bulunmaktadır (Keçeci, 2006). Taşıdığı bazı dezavantajlara karşın ülkemiz açısından ele alındığında karayolu taşımacılığının 2018 yılı itibari ile 266,502 milyon ton olarak gerçekleştiği görülmektedir.

Aşağıdaki tabloda ülkemizde çalışma kapsamında ele alınan döneme ilişkin olarak karayolu yük taşımacılığına ilişkin bazı istatistiki bilgiler verilmektedir.

Tablo 1. Türkiye'de Karayolu Yük Taşımacılığına İlişskin İstatistikler $(1988,2018)$

\begin{tabular}{|c|c|c|c|}
\hline \multicolumn{2}{|c|}{} & 1988 & 2018 \\
\hline \multirow{3}{*}{ Yol Uzunluğu (km)* } & Otoyollar & 151 & 2,842 \\
\cline { 2 - 4 } & Devlet Yolları & 30,999 & 31,021 \\
\cline { 2 - 4 } & İl Yolları & 27,852 & 34,153 \\
\cline { 2 - 4 } & Genel Toplam** & $\mathbf{3 3 0 , 5 1 3}$ & $\mathbf{2 4 7 , 5 5 3}$ \\
\hline \multirow{3}{*}{ Yük Taşıma (ton-km/milyon) } & Otoyollar & $\ldots$ & $\mathbf{6 2 , 1 1 8}$ \\
\cline { 2 - 4 } & Devlet Yolları & $\mathbf{5 9 , 5 0 8}$ & $\mathbf{1 8 3 , 7 0 5}$ \\
\cline { 2 - 4 } & İl Yolları & $\mathbf{5 , 9 5 1}$ & $\mathbf{2 0 , 6 7 9}$ \\
\hline
\end{tabular}


MACIT

\begin{tabular}{|c|c|c|c|}
\hline \multirow{3}{*}{ Seyir (taşıt-km/milyon) } & Otoyollar & --- & 23,616 \\
\hline & Devlet Yolları & --- & 89,045 \\
\hline & İ Yolları & $--\cdot$ & 18,964 \\
\hline Motorlu Kara Taşıtı & Toplamı & $3,140,265$ & $22,865,921$ \\
\hline \multirow{4}{*}{$\begin{array}{c}\text { Yolun Kaplama Cinsine Göre } \\
\text { Uzunluklar (km) }\end{array}$} & Üst Yapılı Yollar & --- & 227,161 \\
\hline & Toprak Yollar & $--\cdot$ & 13,672 \\
\hline & Geçit Vermeyen Yollar & --- & 6,720 \\
\hline & Üst Yapılı Yollar & --- & 280,027 \\
\hline
\end{tabular}

* Uzunluklar yll sonu itibariyledir.

**Köy yolu, bölünmüs yol vb. diğer türlerin genel toplamını vermektedir.

Kaynak: KGM, TÜIK verilerinden derlenmiştir.

Karayolu ile yapılan taşımacılık faaliyeti tüm lojistik süreçlerde yer alması açısından önemli bir ulaştırma türüdür ve günümüzde ulusal ve uluslararası taşımalarda en çok tercih edilen taşıma türüdür (Bayraktutan ve Özbilgin, 2013: 82). Ülkeler arasındaki artan karayolu bağlantıları ve gümrüklerin varlığı ile yük taşımacılığı daha çok kullanılır hale gelmiştir. Otoyolların kilometre uzunluklarının da artmasıyla karayolu ile yapılan taşımacılık hızlı ve güvenli boyutlarda yapılabilir bir nitelik kazanmıştır (Enver, 2012: 3). Yukarıdaki tablodan da görüldüğ̈̈ gibi son otuz yıllık dönemde sadece devlet yollarında yapılan yük taşımacılığı \%209 oranında artış göstermiştir. Eldeki mevcut verilere göre otoyollar kullanılarak yapılan yük taşımacılığı 2001-2018 arası dönemde \%260 oranında bir artış göstermiştir.

Araç sayısındaki artışa paralel olarak taşımacılık faaliyetleri de artış göstermektedir. Ele alınan dönemde karayolu araç sayısı da yaklaşık \%630 oranında bir artış göstermiştir. Ayrıca 2014'te eşya taşıyan kayıtlı firmaların sayısı da 1,400,440 olarak gerçekleşmiştir (UDH, 2014: 21).

Küresel ölçekte değerlendirildiğinde birçok gelişmiş ve gelişmekte olan ülkede olduğu gibi Türkiye'de de karayolu ile yapılan yük taşımacılığı faaliyetleri açık ara diğer ulaştırma modlarına göre ön sırada yer almaktadır. Aşağıdaki tabloda seçilmiş bazı yıllara göre ulaştırma modlarına göre yük taşımacılığı miktarları verilmektedir.

Tablo 2. Türkiye'de Karayolu Yük Taşımacılığına İlişkin İstatistikler (milyon ton) (2010, 2014, 2018)

\begin{tabular}{|c|c|c|c|c|}
\hline & Karayolu & Denizyolu & Demiryolu & Havayolu \\
\hline 2010 & 190,365 & 12,568 & 11,462 & 1,212 \\
\hline 2014 & 234,492 & 15,572 & 11,992 & 2,600 \\
\hline 2018 & 266,502 & --- & 13,514 & 5,949 \\
\hline
\end{tabular}

Kaynak: UDH, İstatistiklerle Ulaştırma Denizcilik ve Haberleşme.

Yukarıdaki tabloda yer alan rakamlara göre 2014 yılında karayolu ile yapılan yük taşımacılığı büyük bir farkla diğer ulaştırma modlarından daha öndedir. Karayolu ile taşınan yük miktarı \%89.5 oranında gerçekleşmişken ikinci sırada bu oranı \%5.9 ile denizyolu yük taşımacılığı takip etmektedir. Küresel düzende güçlü konumda bulunan ülkelerde de diğer ulaştırma 
türlerine göre karayolu ile yapılan ulaşımın daha büyük bir payı olduğu görülmektedir. $\mathrm{Bu}$ rakamlardan da anlaşılacağı gibi bu alanda yapılacak yatırımlar ve uygulanacak politikaların pozitif sonuçları diğer ulaştırma modlarına göre daha etkin olabilecektir. $\mathrm{Bu}$ çerçevede taşımacılık faaliyetlerinin ekonomi üzerindeki etkilerinin belirlenmesi politika yapıcılara geleceğe yönelik hedefler belirleme konusunda yardımcı olabileceği için önem arz etmektedir.

\section{ANALIZZE KULLANILAN DEĞIŞKENLER, YÖNTEM VE TANIMLAYICI İSTATISTIKLER}

Karayolu yük taşımacılığının GSYİH ve ticaret ile ilişkisini ortaya koymak için 1988-2018 arası dönem ele alınarak yıllık veriler ile regresyon analizi gerçekleştirilmiştir. GSYİH, ithalat ve ihracat toplamından oluşan toplam ticaret, karayollarında taşınan toplam yük miktarlarına ilişkin veriler kullanılmıştır. Aşağıda analizde kullanılan verilere ilişkin grafik yer almaktadır.

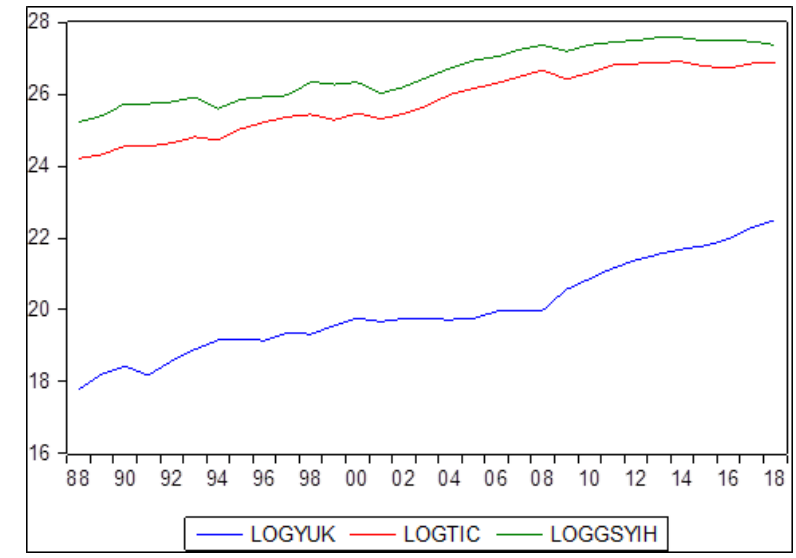

Grafik 1. Toplam Ticaret, Karayolu ile Taşınan Yük Miktarları ve GSYİH (1988-2018)

Yük taşımacılığının; GSYİH üzerindeki etkisini belirlemek için model 1, toplam ticaret üzerinde etkisini ortaya koyabilmek için de model 2 oluşturulmuştur. Regresyon analizi için kullanılan modeller aşağıda verilmektedir.

$$
\begin{array}{ll}
\text { Model 1: } & \operatorname{lnGSYİHt}=\beta 0+\beta 1 \operatorname{lnKYUKt}+\varepsilon t \\
\text { Model 2: } & \operatorname{lnTICt}=\beta 0+\beta 1 \operatorname{lnKYUKt}+\varepsilon t
\end{array}
$$

Yukarıdaki model denklemlerinde de görüldüğü gibi bağımlı değişken olarak GSYİH ve toplam ticaret kullanılırken, açıklayıcı değişken olarak her iki modelde de yük miktarları değişkeni ele alınmıştır. Araştırmada kullanılan veriler TÜİK (Türkiye İstatistik Kurumu) ve KGM (Karayolları Genel Müdürlüğü) kaynaklarından derlenmiştir.

Ele alınan veriler logaritmik değerleri ile analize dahil edilmiştir. Karayolu ile taşınan toplam yük miktarını ifade etmek için LKYUK, toplam ticareti belirtmek için LTIC ve GSYİH logaritmik değerlerini ifade etmek için LGSYİH kısaltmaları kullanılmıştır.

Mal ticareti birçok ülkenin uluslararası ekonomik faaliyetlerinde önemli bir yer tutmaktadır. Cari işlemler hesabında uluslararası hizmetler kapsamında yer alan taşımacılık faaliyetleri; yolcu ve yük taşımacılığı ile kazanılan ve ödenen dövizleri ifade etmektedir. Ulaştırma 
sektörü içim önemli olan konuların başında mal ticareti gelmektedir. $\mathrm{Bu}$ kapsamda değerlendirildiğinde taşımacılık faaliyetlerinin ülke ekonomilerine olan katkıları açıç̧a ortaya çıkmaktadır (Saatçioğlu, 2011: 20). Yük taşımacılığına olan talep miktarlarını ekonomik büyüme, teknolojideki gelişmeler ve nüfus artışları etkilemektedir (Çancı ve Güngören, 2013: 205). Ticaret hacminin artması ile de taşımacılığa olan talep doğaldır ki önemli bir artış gösterebilecektir. Bu nedenle yük taşımacılığının ekonomi ile olan ilişkisini ortaya koyabilmek için toplam ticaret verileri ele alınmıştır.

Ülke ekonomileri açısından önemli ve temel bir diğer gösterge ise GSYH'dir. Bu açıdan karayolu yük taşımacılığının Türkiye'de GSYİH ile olan ilişkisinin de ortaya konabilmesi açısından bu temel gösterge analize dahil edilmiştir. Ulaşımın sanayileşmiş ülkelerde GSYİH'nın önemli bir payını oluşturduğu yaygın olarak kabul edilmektedir. Bu nedenle, tonkm ve GSYİH arasındaki "bağlantı" olarak bilinen korelasyon, geleneksel olarak, yük taşıma talebindeki eğilimleri tahmin etmek için uygulanmıştır, ancak McKinnon ve Woodburn (1996), NEI (1997) ve Kveiborg ve Fosgerau gibi bazı yazarlar (2007), dikkate alınması gereken faktörün GSYİH yerine sanayi sektörü üretimi olduğunu iddia etmektedir (Alises vd., 2014: 187). Bu çalışma kapsamında da GSYİH değerleri ile ticaret hacmi değişkeni analize dahil edilmiştir.

Aşağıdaki tabloda analiz kapsamında ele alınan değişkenlere ilişkin tanımlayıcı istatistikler yer almaktadır.

Tablo 3. Tanımlayıcı İstatistikler

\begin{tabular}{|c|c|c|}
\hline & DGSYIH & DYUK \\
\hline Mean & 0.071087 & 0.157547 \\
\hline Median & 0.071978 & 0.192129 \\
\hline Maximum & 0.373409 & 0.577135 \\
\hline Minimum & $\mathbf{- 0 . 3 2 1 0 7 0}$ & $\mathbf{- 0 . 2 5 2 4 4 3}$ \\
\hline Std. Dev. & $\mathbf{0 . 1 6 7 1 8 0}$ & $\mathbf{0 . 1 7 4 9 1 8}$ \\
\hline Sum & $\mathbf{2 . 1 3 2 6 0 6}$ & 4.726399 \\
\hline Sum Sq. Dev. & $\mathbf{0 . 8 1 0 5 2 1}$ & $\mathbf{0 . 8 8 7 2 9 3}$ \\
\hline Observations & 30 & 30 \\
\hline
\end{tabular}

Değişkenler arasındaki ilişkiyi araştırmaya başlamadan önce, dizinin birim kökü incelenmelidir. Durağan olmayan serilerle yapılan analiz sonucunda, sahte regresyon problemi ile karşılaşılabilir. Serilerin durağanlığının analizi için Genelleştirilmiş DickeyFuller (Augmented Dickey Fuller-ADF) ile Phillips ve Peron (PP) Testleri yapılmıştır. Regresyon analizinde sonuçlara güvenilebilmesi için bazı varsayımların yerine gelmesi gerekmektedir. $\mathrm{Bu}$ amaçla regresyon tahmini gerçekleştirildikten sonra tahmin sonuçlarında varsayımdan sapmalar test edilmiştir. Bu amaçla Jarque-Bera testi, White testi ve LM testleri ile varsayımdan sapmaların sınanması gerçekleştirilmiştir. Aşağıdaki kısımda ekonometrik analize ilişkin kısa bilgi aktarıldıktan sonra test sonuçlarına yer verilmektedir. 


\section{BULGULAR}

Değişkenler arasındaki ilişkilerin anlamlı olabilmesi için ele alınan serilerin durağanlık şartını sağlaması gerekmektedir. Durağanlık; sabit ortalama ile varyans ve seriye ait iki değer arasındaki kovaryansın ele alınan zamana değil, iki zaman değeri arasındaki farka bağlı olması biçiminde tanımlanmaktadır.

Ekonomik değişkenlerin karşılaştığı şokların değişkenlere olan etkileri birkaç dönem sonra ortadan kalkabileceği gibi bunlar kalıcı da olabilmektedir. Ele alınan seriler şoklara göre dalgalanmalar gösterebilmektedir ve bu dalgalanmalara sahip seriler durağanlık özelliğini sağlamazlar. Serilerin durağanlığ 1 ise çeşitli birim kök testleri ile ortaya konmaktadır.

$\mathrm{Bu}$ çalışmada sabit, sabit ve trendli modeller temel alınarak, serilerin durağanlığının analizi literatürde de yaygın olarak kullanılan ADF ve PP birim kök testleri ile sinanmaktadır. Aşağıdaki tabloda ADF ve PP test sonuçları yer almaktadır.

Tablo 4. Birim Kök Test Sonuçları

\begin{tabular}{|c|c|c|c|c|c|c|c|c|}
\hline & \multicolumn{4}{|c|}{ ADF Testi } & \multicolumn{4}{|c|}{ PP Testi } \\
\hline & \multicolumn{2}{|c|}{ Sabit } & \multicolumn{2}{|c|}{ Sabit ve Trend } & \multicolumn{2}{|c|}{ Sabit } & \multicolumn{2}{|c|}{ Sabit ve Trend } \\
\hline & $\begin{array}{c}\mathbf{t} \\
\begin{array}{c}\text { İstatistiğ } \\
\mathbf{i}\end{array} \\
\end{array}$ & $\begin{array}{c}\text { Olasılı } \\
\mathbf{k}\end{array}$ & $\begin{array}{c}\mathbf{t} \\
\begin{array}{c}\text { Istatistiğ } \\
\mathbf{i}\end{array} \\
\end{array}$ & $\begin{array}{c}\text { Olasılı } \\
\mathbf{k}\end{array}$ & $\begin{array}{c}\mathbf{t} \\
\underset{\mathbf{i}}{\text { Istatistiğ }} \\
\mathbf{i}\end{array}$ & 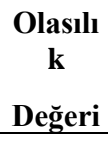 & $\begin{array}{c}\mathbf{t} \\
\underset{\text { İstatistiğ }}{\mathbf{i}} \\
\end{array}$ & $\begin{array}{c}\begin{array}{c}\text { Olasılı } \\
\mathbf{k}\end{array} \\
\text { Değeri } \\
\end{array}$ \\
\hline LTIC & -1.4388 & 0.5501 & -1.4961 & 0.8085 & -1.4388 & 0.5501 & -1.5962 & 0.7705 \\
\hline $\begin{array}{c}\text { LGSYI } \\
\text { H }\end{array}$ & -1.5809 & 0.4797 & -1.7012 & 0.7257 & -1.6072 & 0.4666 & -1.8524 & 0.6536 \\
\hline LKYUK & -1.3481 & $\mathbf{0 . 5 9 3 8}$ & -4.9631 & 0.0031 & -1.3476 & 0.5940 & -1.6560 & 0.7456 \\
\hline & & & $\begin{array}{l}\text { McKinn } \\
\text {-3.6701, }\end{array}$ & $\begin{array}{r}\text { Kritik I } \\
5,-2.963 \\
\end{array}$ & $\begin{array}{l}\text { ğerleri; } \\
\% 10-2.62\end{array}$ & & & \\
\hline
\end{tabular}

Birim kök testi hipotezlerinde H0 hipotezi "birim kök var" anlamına gelmektedir. Tablo sonuçlarında verilen olasılık değerleri eğer anlamlılık düzeylerinden küçük ise H0 hipotezi reddedilerek seride birim kök olmadığı sonucuna ulaşılmaktadır. Yukarıdaki durağanlık analizi için yapılan ADF ve PP test sonuçlarına bakıldığında ele alınan tüm serilerin durağan olmadığı yani birim kök içerdiği görülmektedir. $\mathrm{Bu}$ nedenle tüm serilerin birinci farkları alınarak durağanlıkları sağlanmıştır. Tüm serile I(1) koşulunda durağandır.

Aşağıdaki tabloda her iki model için de regresyon tahmin sonuçları yer almaktadır. Birinci modelde GSYİH ile karayolu yük taşımacılığı arasındaki ilişki ortaya konmakta, ikinci model ile ticaret ile karayolu yük taşımacılığı arasındaki ilişki belirlenmektedir. 
Tablo 5. Regresyon Analizi Sonuçları

\begin{tabular}{|c|c|c|c|c|c|c|c|c|}
\hline \multirow[b]{2}{*}{ Değişken } & \multicolumn{4}{|c|}{$\begin{array}{c}\text { Model 1: } \operatorname{lnGSYIHt}=\beta 0+\beta 1 \ln K Y U K t \\
+\varepsilon t\end{array}$} & \multicolumn{4}{|c|}{ Model 2: $\ln T I C t=\beta 0+\beta 1 \ln K Y U K t+\varepsilon t$} \\
\hline & Katsayı & $\begin{array}{c}\text { Standard } \\
\text { Hata }\end{array}$ & $\begin{array}{c}\text { t- } \\
\text { İstatistik }\end{array}$ & Olasılık & Katsayı & $\begin{array}{c}\text { Standard } \\
\text { Hata } \\
\end{array}$ & $\begin{array}{c}\text { t- } \\
\text { İstatistik }\end{array}$ & Olasılık \\
\hline DLKARA & 0.648242 & 0.362494 & 1.788281 & 0.0846 & 0.6951 & 0.2968 & 2.3417 & 0.0265 \\
\hline C & 0.040750 & $\mathbf{0 . 0 3 3 9 6 7}$ & 1.199682 & 0.2403 & 0.0556 & 0.0278 & 1.9991 & 0.0554 \\
\hline \multicolumn{5}{|c|}{$\mathbf{R}^{2}=\mathbf{0 . 1 0 2 5}$} & \multicolumn{4}{|c|}{$\mathbf{R}^{2}=\mathbf{0 . 1 6 3 7}$} \\
\hline
\end{tabular}

Katsayılar incelendiğinde karayolu yük değişkeninin her iki model için de istatistiksel olarak anlamlı olduğu sonucuna ulaşılmaktadır. DLKARA olasılık değeri 0.10 'dan küçük olduğu için H0 reddedilir, bu değişken \%10 anlamlılık düzeyinde istatistiksel olarak anlamlıdır. Belirlilik sayısı (R2) sonucuna göre ele alınan değişkenin GSYİH'daki değişimi açıklama gücü \%10 iken ticaretteki değişimi açıklama gücü \%16'dır. Her iki model için de $\mathrm{F}$ istatistiğine göre \%10 anlamlılık seviyesinde modelin bir bütün olarak anlamlı olduğu görülmektedir.

Karayolu yük taşımacılığı elastikiyeti ilk modele göre yaklaşık 0.65 'tir. Bu rakama göre karayolu yük taşımacılığı \%1 arttığında GSYİH'nın yaklaşık olarak 0.65 arttığı ifade edilebilmektedir. İkinci model sonucuna göre ise yük taşımacılığı elastikiyeti yaklaşık 0.70 olarak bulunmuştur. Karayolu yük taşımacılığı \% 1 arttığında, ticaret 0.70 artmaktadır.

Yukarıda belirtilen regresyon tahmin sonuçları ile yorumlarının geçerli ve güvenilebilir olması için varsayımdan sapmaların test edilmesi gerekmektedir. Bu amaçla normallik testi, değişen varyans testi ve otokorelasyon testleri ile tahmin sonuçlarının geçerliliği sınanmıştır. Öncelikle hata terimlerinin normal dağılıp dağılmadıklarını test etmek için Jarque-Bera normallik testi yapılmıştır. Her iki model için test sonuçları aşağıdaki tabloda verilmektedir.

Tablo 6. Normallik Testi (JB) Sonuçları

\begin{tabular}{|l|l|l|}
\hline & Model 1 & Model 2 \\
\hline Ortalama & -0.0000 & 0.0000 \\
\hline Medyan & -0.0108 & 0.0043 \\
\hline Max. & 0.3246 & 0.2379 \\
\hline Min. & -0.3428 & -0.2876 \\
\hline Çarpıklık & -0.0422 & -0.2323 \\
\hline Basıklık & 2.7628 & 2.4337 \\
\hline & JB $=0.079192$ & JB $=0.6707$ \\
& Olasıl1k $=0.961178$ & Olas1l1k $=0.7150$ \\
\hline
\end{tabular}


Yukarıdaki tablo incelendiğinde JB test sonucunun model 1 için 0.0791 olduğu görülmektedir. H0 hipotezi serilerin normal dağıldığını ifade etmektedir. Olasılık değeri, $0.9611>0,05$ olduğu için H0 hipotezi reddedilememektedir ve kalıntıların normal dağıldığ sonucuna ulaşılmaktadır. Benzer şekilde model 2 için JB test sonucu 0.6707 olarak bulunmuştur ve test istatistiğinin 5.99 değerinden küçük olması hata terimlerinin normal dağıldığını ifade etmektedir. Ayrıca çarpıklık ve basıklık değerlerinin de sırasıyla 0 ve 3 ya da bunlara yakın değerlerde olması beklenmektedir. Her iki modelin bu değerleri ele alındığında beklenen değerlere yakın oldukları görülmektedir. Sonuç olarak regresyon modelinin ilk varsayımı her iki model için de sağlanmaktadır.

Regresyon analizinde bir başka varsayımdan sapma ise otokorelasyon olup olmadığının test edilmesi gerekliliğidir. Bunun için Breusch-Godfrey LM testi uygulanmıştır. Aşağıdaki tabloda her iki modele ait 1 ve 27 gecikme için LM test sonuçları yer almaktadır.

Tablo 7. Otokorelasyon Test Sonuçları (LM Testi)

\begin{tabular}{|l|l|l|l|}
\hline \multirow{4}{*}{ Model 1 } & Gecikme Sayıs1 & $\mathrm{n} * \mathrm{R}^{2}$ & Olasılık \\
\cline { 2 - 4 } & 1 & 0.5551 & 0.4562 \\
\cline { 2 - 4 } & 27 & 29.9948 & 0.3144 \\
\hline \multirow{3}{*}{ Model 2 } & 1 & $\mathrm{n}^{*} \mathrm{R}^{2}$ & Olas1lı \\
\cline { 2 - 4 } & Gecikme Sayı1s1 & 0.2110 & 0.6459 \\
\cline { 2 - 4 } & 27 & 29.6608 & 0.3296 \\
\hline
\end{tabular}

LM testi için tüm gecikme uzunları dikkate alınmış ve otokorelasyon sorununa her iki modelde de rastlanmamıştır. Tüm gecikmeler için olasılık değerleri \%5 anlamlılık düzeyinden büyük olduğu için $\mathrm{H} 0$ otokorelasyon yoktur hipotezi reddedilememektedir.

Varsayımdan sapmaların belirlenmesinde sonraki aşamada ise değişen varyans sorunu olup olmadığını belirlemek için White testi uygulanmıştır. Aşağıdaki tabloda test sonuçları verilmektedir.

Tablo 8. Değișen Varyans Test Sonuçları (White Testi)

\begin{tabular}{|l|l|l|l|}
\hline \multicolumn{2}{|c|}{ Model 1 } & \multicolumn{2}{c|}{ Model 1 } \\
\hline $\mathrm{n} * \mathrm{R}^{2}$ & Olasilik & $\mathrm{n} * \mathrm{R}^{2}$ & Olas1lik \\
\hline 0.0653 & 0.7982 & 0.0098 & 0.9211 \\
\hline
\end{tabular}

Yukarıdaki test sonucuna göre, olasılık değeri \%5 anlamlılık düzeyinden büyük olduğu için H0 değişen varyans yoktur hipotezi reddedilememektedir. Her iki modelde de sabit varyans vardir.

Tahmin edilen her iki regresyon denklemi için de varsayımdan sapmalar test edildiğinde herhangi bir soruna rastlanmamıştır. $\mathrm{Bu}$ anlamda elde edilen sonuçlara ve yorumlara güvenilebileceği ortaya konmuştur. 


\section{SONUÇ VE ÖNERILLER}

Ulaştırma sektörü, istihdam yaratıcı bir sektör olmasının yanı sıra mal akışlarını düzenleyerek ticaret hacmine katkıda bulunması bakımından ekonomik büyümeye katkı sağlayan önemli sektörlerden biri konumundadır. Taşımacılık imkanları iyileştikçe üretim, yatırım ve istihdam gibi temel makro iktisadi göstergelerde de iyileşmeler gerçekleşecektir. Küresel arenada yaşanan hızlı gelişmelerin, teknolojik değişimlerin ve ticaret hacmindeki artışların hepsi birlikte değerlendirildiğinde taşımacılık sektörünün ülke ekonomisine sağlayacağı katkılar yadsınamaz bir gerçektir.

Türkiye'de karayolu yük taşıma miktarları ile GSYIH ve ticaret ilişkisinin tahmin edildiği bu çalışma sürdürülebilirlik açısından önem taşımaktadır. 1988-2018 arası dönem ait 30 yıllık veriler ile yük taşımacıllğının iki ekonomik gösterge ile olan ilişkisi ekonometrik analizle ortaya konmuştur. Çalışmanın temel bulgusuna göre GSYIH ve ticaret ile karayolu yük taşımacılığı arasında anlamlı bir ilişki bulunmuştur. Karayolu yük taşımacılığı $\% 1$ arttığında GSYIH'nın yaklaşık olarak 0.65 arttığı tahmin edilmiştir. İkinci model sonucuna göre ise karayolu yük taşımacılığı \%1 arttığında, ticaretin 0.70 arttığı tahmin edilmiştir. Ortaya konan bu temel bulgular neticesinde, Türkiye'de karayolu yük taşımacılığı arttıkça GSYİH ve ticaretin de artacağı söylenebilmektedir. Çalışmadan elde edilen bu temel bulgular; ekonomik göstergeler ve karayolu taşımacıllk sektörü arasındaki ilişkiye yönelik literatürdeki çalışmaları (Bozkurt vd. (2017), Lan vd. (2017), Rashidi ve Samimi (2012), Kaynak ve Mert (2009), Zhu vd. (2007)) destekler niteliktedir. Ayrıca sonuçlar, demiryolu ve havayolu taşımacılığına ilişkin yapılan çalışmaların (Hakim ve Merkert (2016), Pradhan ve Bagchi (2013), Gürlü (2019)) ortaya koyduğu ekonomik büyüme ve taşımacılık arasındaki ilişki ile de benzerlik taşımaktadır.

Karayolları yatırımlarına yönelik olarak yapılan sosyo-ekonomik araştırmalardan elde edilen temel bulgular, yatırımların yüksek katma değer yarattıklarını ortaya koymaktadır. Bu sektöre yapılan/yapılacak yatırımlar ekonomiye doğrudan ve dolaylı olarak etkiler sağlamasının yanı sıra üretim ve istihdama da katkı sağlamaktadır. Ayrıca maliyetlerin azaltılması ile verimliliği arttırma yönünde de olumlu etkiler meydana getirmektedir. Tüm bunlara ek olarak kara yollarının geliştiği bölgeler, daha az yatırımların aktarıldığı bölgelere kıyasla daha yüksek bir gelişme düzeyine sahip bulunmaktadır.

Ulaştırma alanında yapılacak altyapı yatırımları taşıma maliyetlerini düşürerek ekonomi üzerinde pozitif bir etki meydana getirecektir. Yatırımlar ve üretim üzerindeki olumlu katkıları ile istihdam ve ticareti arttırabilmektedir. Ulaştırma ve taşımacılık alanındaki ekonomik yararları ortaya koyan çalışmalar literatürde her geçen gün artmaktadır. Küresel ekonomide güçlü bir konumda olan ülkelerin ulaştırma alanında en çok karayolunu tercih ettikleri görülmektedir. Karayolu ulaştırmada yük taşımacılı̆̆ının konu alındığı bu çalışmada regresyon analizi sonucunda Türkiye'de karayolu yük taşımacılığında meydana gelen değişimin ekonomik büyüme ve ticaret hacmi üzerinde pozitif yönde bir etkisi olduğu sonucuna ulaşılmıştır. Literatürde yapılan çalışmalarda farklı değişkenler ve farklı ulaştırma modları üzerinden ele alınan analizlerde pozitif sonuçların elde edildiği görülmektedir.

Türkiye'nin kıtalar arası taşıma rotalarının kavşağında yer alması, jeostratejik açıdan önemini arttırmaktadır. Bu durumun etkisi ile ülkemiz bu sektördeki etkinliğini arttırabildiği ölçüde küresel rekabette güç kazanabilecektir. Ülkemizin coğrafi konumundaki üstünlüğünden fayda yaratabilmesi için altyapı yatırımlarının sağlam temelleri olması gerekmektedir. 
Karayolu sistemindeki denetim eksiklikleri ve altyapı eksiklikleri gibi nedenler sektörde faaliyet gösteren firmaların maliyetlerini arttırmaktadır. Karayolu taşımacılığında maliyetlerin yüksek oluşu ise belirli bölgelerde yoğunlaşma yaratmakta ve üretim-tüketim dengesini bozucu yönde etki yapmaktadır. Ülkemiz petrol ithal eden bir konumda olduğu için karayolu ulaştırma maliyetlerinin yüksek olması, netice olarak mal ve hizmetlerin fiyatlarını arttırıcı yönde baskı yaratmaktadır. Yüksek maliyetli bir ulaştırma politikasının sürdürülmesi hanehalkının gelirini düşürücü etkiler yaratmaktadır.

Sektördeki taşımacılık faaliyetlerini arttıracak çalışmalar için sektör temsilcileri ve ilgili kamu kurum ve kuruluşlarının işbirliği içerisinde olması gerekmektedir. Ulaştırma ve taşımacılık faaliyetlerinde zamanın önemli olmasından dolayı kombine taşımacılığın öneminin de vurgulanması gerekmektedir. Ulaştırma modları arasındaki uyum sağlanarak entegrasyonlu bir taşımacılık sistemini destekleyecek altyapı yatırımlarının gerçekleştirilmesi gerekmektedir. Karayolu yük taşımacılığının gelişebilmesi için altyapı yatırımlarının arttırılması, karayolu bağlantılarının güçlendirilmesi, sektöre teşviklerin verilmesi, hukuki zeminlerin güncellenmesi, sektörde istihdam edilenlerin çalışma şartlarının iyileştirilmesi, denetimlerin yapılması, karayolu ağlarının mesafe olarak değil aynı zamanda nitelik olarak da kalitesinin iyileştirilmesi gibi gelişmeler sektöre katkı sağlayacak unsurlardır. Karayolu yük taşımacılığında küresel düzende rekabet edebilir boyuta gelebilmek için gerekli politika önlemlerinin arttırılması hem mevcut taşıyıcı işletmelerin rekabet düzeylerini arttırması yönünden hem de ekonomiye sağlayacağı uzun dönemleri katkıları nedeni ile önem taşımaktadır.

\section{KAYNAKÇA}

ALISES, A., VASSALlO, J. M., \& GUZMÁN, A. F. (2014). Road freight transport decoupling: A comparative analysis between the United Kingdom and Spain. Transport Policy, 32, 186-193.

BARDA, S. (1970). Modern Ulaştırma Koordinasyon Ekonomisi ve Türkiye'nin İmkanları, MPK Yayınları, Ankara.

BOWERSOX, D. J., CLOSS, D. J., COOPER, B. M., \& BOWERSOX, J. C. (2013). Supply Chain Logistics Management. Fourth Edition. Newyork. McGraw-Hill. 10-311.

BOZKURT, E., EFEOĞLU, R., SEVİNÇ, H., \& ALTUNER, İ. (2017). Türkiye ve Avrasya Ekonomilerinde Taşımacılık Sektörünün Ekonomik Büyümeye Etkisi. Igdir University Journal of Social Sciences, (11).

CAID N. (2004). Analysis of the Link Between Transport and Economic Growth. OECD Rapor. 1-94.

COYLE, J.J., NOVACK, R. A., GIBSON, B. J., \& BARDI, E., (2011) "Transportation: A Supply Chain Perspective”, 7th Edition, South-Western Cengage Learning, USA.

ÇANCI, M., \& GÜNGÜREN, M. (2013). İktisadi Yaşamda Taşımacılık Sektörü. Elektronik Sosyal Bilimler Dergisi, 12(45), 198-213.

DENIZ, T. (2016). “Türkiye'de Ulaşım Sektöründe Yaşanan Değişimler ve Mevcut Durum”, Doğu Coğrafya Dergisi, 36, 135-156.

DOĞAN, A. (2014). Kara Yolu Yük Taşımacılığı. İstanbul: Beta Yayınları. 
DÜNYA EKONOMİ GAZETESİ (09 Aralık 2017). UND Başkanı: Karayolu Taşımacılığında En Büyük Sorun Gümrük, https:/www.dunya.com/ekonomi/und-baskani-karayolutasimaciliginda-en-buyuk-sorun-gumruk-haberi-393852 (Erişim Tarihi: 03.09.2020).

GTB (T.C. Gümrük ve Ticaret Bakanlığı), 2014. Kooperatif İstatistikleri Bülteni, http://koop.gtb.gov.tr/data/52ce773b487c8e3b38d8fa65/Koop\%C4\%B0statistik\%2010\%2001\%20(2).pdf (Erişim Tarihi: 10.09.2020).

GTB (T.C. Gümrük ve Ticaret Bakanlığı), 2017. Türkiye Kooperatifçilik Raporu 2016, http://koop.gtb.gov.tr/data/592ea2dd1a79f514ac499aae/TKR-2016-2017\%200804-

BASIM.pdf (Erişim Tarihi: 10.09.2020).

GÜNDOĞDU, F. (2013). Karayolu yük taşımacılığı çalışanlarının mesleki problemleri ve bu problemlerin sosyal ve ekonomik yansımaları üzerine bir uygulama: Burdur-Bucak örneği (Doctoral dissertation, SDÜ Sosyal Bilimler Enstitüsü).

GÜRLÜ, S. (2019). Türkiye'de Hava Ulaştırma Sektörü ve İktisadi Büyüme Üzerindeki Etkisi, İstanbul Üniversitesi, SBE, Yayımlanmamış Yüksek Lisans Tezi.

GWILliAM, K. M., Transport and Public Policy, London: George Allen \& Unwin Ltd., 1964.

HAKIM, M. M., \& MERKERT, R. (2016). The causal relationship between air transport and economic growth: Empirical evidence from South Asia. Journal of Transport Geography, 56, 120-127.

HONG-WEN, Z., HONG-YAN, W., \& YU-MIN, Z. (2007, August). The research of relationship between economy development and logistics development based on statistical analysis. In 2007 International Conference on Management Science and Engineering (pp. 1372-1377). IEEE.

HOSSEIN RASHIDI, L., \& SAMIMI, A. (2012). Relationship between economic and transportation infrastructure indicators and freight productivity growth. Journal of urban planning and development, 138(3), 254-262.

KARABIÇAK, M., \& GÜNDOĞDU, F. (2014). "Karayolu Yük Taşımacılığı Çalışanlarının Mesleki Problemleri ve Bu Problemlerin Sosyal ve Ekonomik Yansımaları Üzerine Bir Uygulama: Burdur-Bucak Örneği”, Emek ve Toplum Dergisi, 3 (6), 178-199.

KARLUK, R. (2009) “Cumhuriyetin İlanından Günümüze Türkiye Ekonomisinde Yapısal Dönüşüm”, Beta Basım, İstanbul.

KAYA, S. (2008), “Türkiye'de Ulaştırma Sektörünün Genel Görünümü ve Sorunları”, ARGE Bülten, Şubat, 31-38.

KAYODE, O., BABATUNDE, O., \& ABIODUN, F. (2013). An empirical analysis of transport infrastructure investment and economic growth in Nigeria. Social Sciences, 2(6), 179-188.

KEÇECI, A. (2006). “Türkiye'de Karayolu Taşımacılığı”. Uluslararası Ekonomik Sorunlar Dergisi, 20. http://www.mfa.gov.tr/turkiye_de-karayolu-tasimaciligi-.tr.mfa (Erişim Tarihi: 15.01.2019). 
KGM (KARAYOLLARI

GENEL

MÜDÜRLÜĞ̈̈), https://www.kgm.gov.tr/Sayfalar/KGM/SiteTr/Istatistikler/DevletveIlYolEnvanteri.asp $\mathrm{x}$ (Erişim Tarihi: 01.10.2019).

KGM (KARAYOLLARI GENEL MÜDÜRLÜĞÜ), (2005). “Stratejik Plan 2006-2010”, Karayolları Genel Müdürlüğü Yayını, Ankara.

KGM

(KARAYOLLARI

GENEL

MÜDÜRLÜĞ̈̈), https://www.kgm.gov.tr/SiteCollectionDocuments/KGMdocuments/Istatistikler/Devlet IlYolEnvanter/SatihYolAgiUzunlugu.pdf (Erişim Tarihi: 12.11.2019).

KÖGMEN, Z. (2014). Karayolu Taşımacılığının Diğer Taşımacılık Modlarıyla Karşılaştırılması ve Sağladığı Avantajlar. Ulaştırma ve Haberleşme Uzmanlık tezi). Ulaştırma, Denizcilik ve Haberleşme Bakanlığı, Ankara.

KPMG, (2020). Taşımacılık: Sektörel Bakış, https://assets.kpmg/content/dam/kpmg/tr/pdf/2020/03/sektorel-bakis-2020tasimacilik.pdf (Erişim Tarihi: 16.09.2020).

McKINNON, A. (2006). Life without trucks: the impact of a temporary disruption of road freight transport on a national economy. Journal of Business Logistics, 27(2), 227-250.

McKINNON, A. C. (2007). Decoupling of road freight transport and economic growth trends in the UK: An exploratory analysis. Transport Reviews, 27(1), 37-64.

PHILliPS, P. C. P., \& PERRON, P. (1988), “Testing for a Unit Root in Time Series Regression". Biometrika, 75.

PRADHAN, R. P., \& BAGCHI, T. P. (2013). Effect of transportation infrastructure on economic growth in India: the VECM approach. Research in Transportation Economics, 38(1), 139-148.

SAATÇİOĞLU, C. (2011). Ulaştırma Ekonomisi: Teori ve Politika, Gazi Kitabevi, Ankara.

SEZER, S. (2018). The Impact of Logistics Sector on Economic Growth: Examination of BRICS Countries and Turkey. https://seville2019.econworld.org/papers/Sezer_TheImpact.pdf (Erişim Tarihi: 20.10.2019).

T. C. ULAŞTIRMA BAKANLIĞI, 1993, Cumhuriyetin 70. Yılında Ulaştırma, Haberleşme.

T.C. KALKINMA BAKANLIĞI, (2014). Onuncu Kalkınma Planı (2014-2018): 2015 Yıl1 Program1, http://www.sbb.gov.tr/wpcontent/uploads/2018/11/2015_Yili_Programi.pdf (Erişim Tarihi: 03.09.2020).

TAKIM, A., \& ERSUNGUR, Ş. M. (2015). Taşıma Şekillerine Göre Türkiye'de Dış Ticaretin Analizi: Mevcut Durum, Sorunlar ve Beklentiler. Journal of Graduate School of Social Sciences, 19(3).

TÜİK (Türkiye İstatistik Kurumu). Ulaştırma İstatistikleri. http://www.tuik.gov.tr/PreTablo.do?alt_id=1051 (Erişim Tarihi: 03.10.2019).

UDH (T.C. Ulaştırma Denizcilik ve Haberleşme Bakanlığı), (2014). İstatistiklerle Ulaştırma Denizcilik 
https://www.utikad.org.tr/images/BilgiBankasi/istatistiklerleulastirmadenizcilikvehabe rlesme20032014-6245.pdf (Erişim Tarihi: 03.11.2019). 